\title{
Risk factors for a high somatic cell count at the first milk recording in a large sample of UK dairy herds
}

\author{
A. Madouasse,${ }^{\star 1}$ W. J. Browne, $†$ J. N. Huxley, ${ }^{\star}$ F. Toni, $\neq$ A. J. Bradley, ${ }^{\star} \S$ and M. J. Green ${ }^{\star}$ \\ *University of Nottingham, School of Veterinary Medicine and Science, Sutton Bonington Campus, Sutton Bonington, Leicestershire, LE12 5RD, \\ United Kingdom \\ †School of Veterinary Science, University of Bristol, Langford, Bristol, BS40 5DU, United Kingdom \\ ¥Pfizer Animal Health Europe, Africa and Middle East (EuAfME), 23-25 avenue du Dr Lannelongue, F-75668 Paris Cedex 14, France \\ $\S$ Quality Milk Management Services (QMMS) Ltd., Westbury-sub-Mendip, Nr Wells, Somerset, BA5 1EY, United Kingdom
}

\begin{abstract}
The dry period is important for the cure of existing intramammary infection (IMI) and the acquisition of new IMI. Somatic cell count (SCC) at both the last milk recording before drying off and at the first milk recording following calving can be used on farm to describe the dynamics of IMI during the dry period. The aims were to quantify the association between the main risk factors collected from milk recording data and the occurrence of a high SCC in early lactation as well as to partition the observed variation into the prevalence of high SCC in within-herd and between-herd variation. Milk recording data collected between 2004 and 2006 from 2,000 herds in England and Wales were used. Cows with an SCC $\geq 200,000$ cells/mL were classified as high, and other cows as low. The median prevalences of the high classification were 42 and $21 \%$ at the last milk recording before drying off and the first milk recording following calving, respectively. Cows classified high or producing more milk before drying off as well as cows of greater parity or recorded in early lactation were more likely classified high at the first recording following calving. Cows from herds in which the prevalences of the high classification or the probability of remaining or becoming high over the dry period were elevated during the previous year were more likely classified as high at the first recording following calving. Half of the variability in the proportion of cows with a high SCC after calving originated at the herd level. The other half was unexplained within herd, but by between-year variability. Most cow-level predictors were important in explaining individual cow performance, but accounted for little of the overall between-herd variability. Of the predictors identified as important at the cow level, only milk yield at drying off was important in explaining the between-herd variability.
\end{abstract}

Received August 4, 2011.

Accepted December 2, 2011.

${ }^{1}$ Corresponding author: Aurelien.Madouasse@oniris-nantes.fr
Key words: somatic cell count, dry period, Bayesian model, multilevel logistic regression

\section{INTRODUCTION}

The dry period is a critical time for the mammary gland during which IMI present at the end of lactation can be cured, but also new infections are acquired (Bradley and Green, 2000; Dingwell et al., 2004). Infections carried through or acquired during the dry period can result in clinical mastitis during the subsequent lactation (Green et al., 2002; Pantoja et al., 2009b). In terms of IMI detection, the gold standard is considered bacteriology and, as such, is used in most epidemiological studies. Bacteriology is not routinely available or practical on most farms and farmers must rely on other indicators to assess their performance. The SCC data are commonly available in the UK and high values are indicative of mastitis (Schukken et al., 2003; Bradley and Green, 2005). Various thresholds have been proposed to classify cows as infected or uninfected. A threshold of 200,000 cells/mL is most frequently used, at least in the UK. In a single US herd, this threshold had a sensitivity of 0.47 and a specificity of 0.82 for the detection of subclinical mastitis at the first milk recording in lactation (Pantoja et al., 2009a). Those authors included minor pathogens in their definition of IMI. In the same study, increasing the threshold from 50,000 to 300,000 cells $/ \mathrm{mL}$ resulted in a decrease in sensitivity from 0.86 to 0.30 and an increase in specificity from 0.40 to 0.88 . Therefore, a threshold of 200,000 cells $/ \mathrm{mL}$ is a good compromise between sensitivity and specificity, even at the beginning of lactation.

In the past decade, 2 studies have described the between-herd variability in SCC dynamics across the dry period: 1 in the United Kingdom (Madouasse et al., 2010b) and 1 in the United States (Cook et al., 2002). Both used a threshold of 200,000 cells/mL. Important variations existed in the apparent cure and new IMI rates. In Madouasse et al. (2010b), the apparent new IMI rate was $6.4 \%$ for herds at the tenth best percentile 
and $31.2 \%$ for herds at the tenth worst percentile. For the apparent cure rate, the values were 88.9 and $54.3 \%$ for the best and worst tenth percentiles, respectively. In Cook et al. (2002), important differences existed between herds. The apparent new IMI rate ranged between 0 and $71 \%$ and the apparent cure rate between 20 and $100 \%$. In these 2 studies, the reasons for variation were not explored. For example, most studies on the dry period have found parity and milk yield before drying off to be risk factors of mastitis postpartum (Dingwell et al., 2004; Green et al., 2007; Pantoja et al., 2009b). Although this information is available in milk recording data, whether these 2 factors are important in explaining the between-herd variability is unknown.

The aims were to quantify the association between the main factors available in milk recording data and the occurrence of a high SCC in the first milk recording after calving, and to quantify the proportion of observed variation in the prevalence of high SCC after calving that occurred either within herds or between herds.

\section{MATERIALS AND METHODS}

\section{Data}

A large sample of milk recording data collected in 2,000 herds from England and Wales between January 2004 and December 2006 was used for analysis. The data selection process was described in detail in Madouasse (2009). Briefly, data from consecutive monthly milk recordings in herds milking at least $80 \%$ of Holstein-Friesian cows were used. The last milk recording in a lactation and the first recording following calving were extracted from the database for all cows. For the first recording in the following lactation, data were omitted when the first milk recording after calving occurred later than $35 \mathrm{~d}$ after calving. The date of drying off was unknown. It was, therefore, not possible to put any constraint on the interval between the last milk recording in lactation and drying off.

\section{Definitions}

The SCC $<200,000$ cells $/ \mathrm{mL}$ were labeled low and SCC $\geq 200,000$ cells/mL were labeled high. Between the last recording in a lactation and the first recording in the subsequent lactation, cows moving from low to high were considered new IMI and cows moving from high to low were considered cures. A variable high at dry off $\left(\mathbf{H}_{\text {dof }}\right)$ was created that took the value 1 when a cow had a high SCC at the last recording before drying off and 0 otherwise. A variable high after calving $\left(\mathbf{H}_{\text {calv }}\right)$ was created that took the value 1 when a cow had a high SCC at the first recording after calving and 0 otherwise. Using these definitions, the cure rate was described as $p\left(H_{\text {calv }}=0 \mid H_{\text {dof }}=1\right)$ and the new infection rate as $p\left(H_{\text {calv }}=1 \mid H_{\text {dof }}=0\right)$.

\section{Initial Exploration and Modeling}

Cure and new IMI rates as described above and their association with the variables available in the data set were explored in R ( $\mathrm{R}$ Development Core Team, 2010). Milk yield, parity at drying off, calving date, and DIM at the first milk recording in a lactation were the cow-level information that was investigated and it was accepted that unexplained variation would remain at both cow and herd levels. Data were aggregated by herd-year; that is, summaries for the prevalence of high SCC before drying off, cure rate, and new IMI rate during the dry period were calculated for every herd and for each of the 3 available years. This was to allow the modeling of the performance of a given year as a function of what happened during the previous year, thereby splitting the variability between structural herd characteristics and year-to-year variation.

Distributions of the available variables were plotted and percentiles calculated. To explore the associations between the different variables, cure rate and new IMI rate as described above were modeled in $\mathrm{R}$ with multilevel logistic models using the lmer function from the lme4 package (Bates and Maechler, 2010). Modeling was carried out at the cow-lactation level and a herd random intercept was included in each model. For continuous variables, polynomials (powers 1 to 3 ) of the covariates were entered in the models to account for possible nonlinear associations. For date of calving, sine and cosine transformations were applied to the day of the year at calving as in Madouasse et al. (2010a). Associations between covariates and either cure or new IMI rates were deemed significant for model coefficients that were at least 2 standard errors from 0.

\section{Model 1: Cow-Lactation Probability of High SCC After Calving}

Overview. The aim of the first model was to describe the association between cow and herd-year level predictors and lactation level probabilities of new IMI and cure. New IMI and cure rates for cows calving in 2005 were modeled as a function of herd prevalence of high SCC, new IMI, and cure rates for cows calving in 2004 as well as cow-level information for 2005.

Model Specification. The model specification was 


$$
\begin{gathered}
H_{\text {calvij }_{i j}} \sim \operatorname{Bernoulli}\left(p_{i j}\right) \\
\operatorname{logit}\left(p_{i j}\right)=H_{d o f}\left(\alpha^{c}+u_{j}^{c}+\mathbf{X}_{i j} \boldsymbol{\beta}^{c}\right)+\left(1-H_{d o f}\right)\left(\alpha^{N}+u_{j}^{N}+\mathbf{X}_{i j} \boldsymbol{\beta}^{N}\right) \\
u_{j}^{c}, u_{j}^{N} \sim M V N\left(0, \boldsymbol{\Sigma}_{u}\right),
\end{gathered}
$$

where the outcome of the model, $H_{\text {Cal }_{i j}}$ for lactation $i$ in herd $j$, was an indicator variable taking the value 1 when a cow had a high SCC at the first milk recording after calving and 0 otherwise. This outcome occurred with a probability $p_{i j}$ and was modeled on a logit scale as following a Bernoulli distribution. The model allowed for 2 different scenarios:

- If the cow had a high SCC at the last recording before drying off, the indicator variable $H_{d o f}$ took the value 1 and $1-H_{\text {dof }}$ was 0 . This was, in effect, modeling the probability of not curing or, that is, the probability of remaining high; $\alpha^{c}$ was the overall mean log odds probability for this event, $u_{j}^{c}$ was the herd-specific deviation from this mean, $\mathbf{X}_{i j}$ was the matrix of covariates and $\boldsymbol{\beta}^{c}$ the associated vector of coefficients.

- If the cow had a low SCC at the last recording before drying off, the indicator variable $1-H_{d o f}$ took the value 1 and $H_{\text {dof }}$ was $0 ; \alpha^{N}$ was the overall mean log odds probability of new IMI, $u_{j}^{N}$ was the herd-specific deviation from this mean, $\mathbf{X}_{i j}$ was the matrix of covariates and $\boldsymbol{\beta}^{N}$ the associated vector of coefficients.

The herd random effects $u_{j}^{c}$ and $u_{j}^{N}$ followed a bivariate normal distribution $(M V N)$ with mean 0 and variance-covariance matrix $\boldsymbol{\Sigma}_{u}$. Parameters were estimated in a Bayesian framework using Markov chain Monte Carlo (MCMC), in WinBUGS (Lunn et al., 2000). Model parameters were given normal prior distributions of mean 0 and variance 1,000. The variance-covariance matrix was modeled using the scaled inverseWishart distribution as described in Gelman and Hill (2007). Hierarchical centering (Browne et al., 2009), which consisted in modeling the means of the intercepts at the herd level, was used to speed up the convergence of the chains estimating the random effects. To remove the correlation between the different powers of the same continuous variables, Legendre polynomials were used instead of raw polynomials (Bohmanova et al., 2008).

Model Building. For each model, 3 chains were run and convergence assessed visually. The deviance information criterion (DIC) was used to compare models (Spiegelhalter et al., 2002). Parameters were retained when their inclusion resulted in a decrease in the DIC and when the credible interval did not include 0. Models converged before 10,000 iterations and were run for 10,000 more iterations for the calculation of parameter summaries. For individual herd intercepts, summary statistics were calculated for 1,000 iterations, as their value was less critical to assess the model fit, and, each iteration resulted in 4,000 individual values, which was prohibitive in terms of computation.

Model Checking. Conventional posterior predictions were used to predict the probability of a cow having a high SCC at the first milk recording after calving. Mean predicted proportions of high SCC were calculated for different subgroups, also called bins, of interest and plotted against observed proportions (Gelman et al., 2000). For continuous variables (milk yield at the last recording and day of the year), bins were created based on the variable's percentiles. When the variable could only take a limited number of values (e.g., parity and DIM), a group was created for each level of the variable. The same procedure was carried out with data grouped by herd.

The relative importance of the covariates included in the final model in explaining the between-herd variability was evaluated. A full herd-level prediction of the prevalence of high SCC at the first milk recording in lactation including all the model covariates was initially calculated. The same procedure was then carried out, but excluding each covariate at a time. The proportion of the between-herd variation explained by each submodel was investigated using linear models with the vector of observed proportions as the dependent variable and the vector of predicted proportions as the independent variable. The proportion of the variance explained was estimated using the adjusted coefficient of determination of these models and the variation explained by different subsets of covariates was evaluated.

Posterior Predictive Simulations. The effect of each variable retained in the final model on the new IMI and cure rates was further investigated through posterior predictive simulation (Gelman et al., 2000). For each simulation, all variables were kept at a meaningful value except the variable under investigation that was varied over a plausible range. For each value of the investigated variable, 1,000 new IMI and cure rates were generated from the applicable posterior distribution. The median, the 2.5th percentile, and the 97.5th percentile were stored and assessed graphically.

\section{Model 2: Between-Herd and Between-Herd-Year Variability in the Prevalence of High SCC After Calving}

Overview. The aim of the second model was to explore the relative importance of the between-herd 


\section{Distribution of parities at drying off}

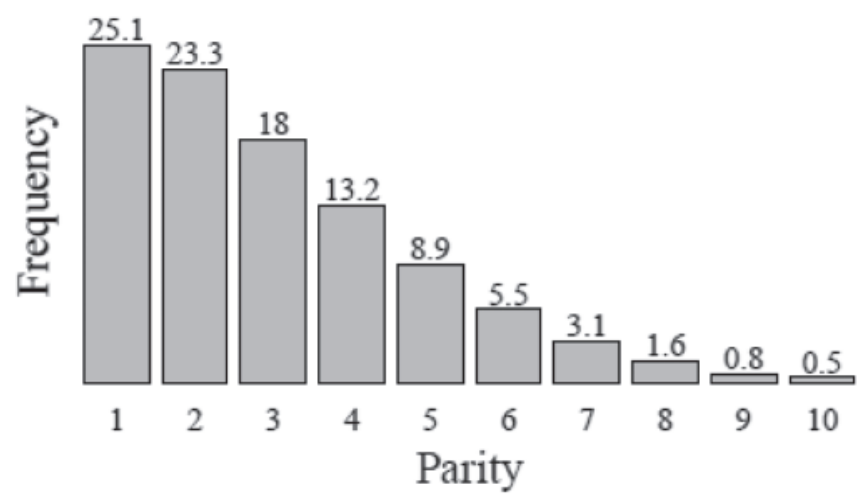

Milk yield at the last recording before drying off

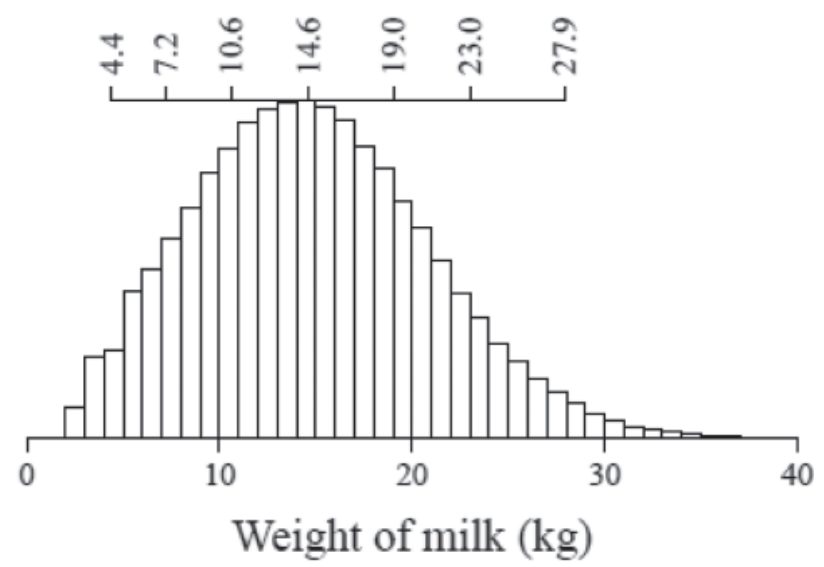

Number of calvings per month

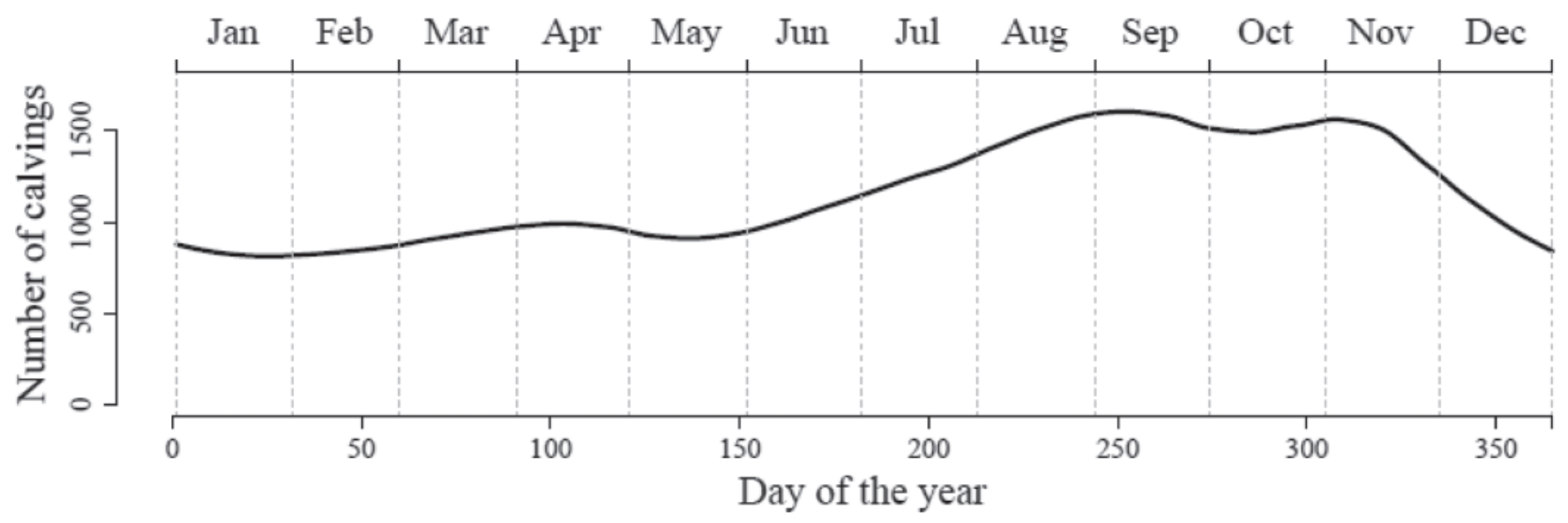

Figure 1. Distribution of the variables related to cow characteristics for cows calving in 2004 and 2005 in 2,000 herds. For parities, the numbers above the bars represent the percentage of calvings in each group. For milk yield at the last milk recording before drying off, the bar at the top gives percentiles $2.5,10,25,50,75,90$, and 97.5 of the distribution.

variability and the within-herd between-year variability in the proportion of cows with a high SCC at the first milk recording in lactation.

Model Specification. The model specification was

$$
\begin{aligned}
& Y_{i j}=\alpha+ \operatorname{Calv}_{04} \beta_{1}+\operatorname{Calv}_{06} \beta_{2}+u_{j}+\varepsilon_{i j} \\
& u_{j} \sim \operatorname{Normal}\left(0, \sigma_{j}^{2}\right) \\
& \varepsilon_{i j} \sim \operatorname{Normal}\left(0, \sigma_{i j}^{2}\right)
\end{aligned}
$$

where $Y_{i j}$ was the proportion of high SCC at the first milk recording in lactation for year $i$ in herd $j$; $\alpha$ was the intercept of the model; $\mathrm{Calv}_{04}$ was an indicator variable taking the value 1 for the year 2004 and 0 otherwise; $C_{a l v_{06}}$ was an indicator variable taking the value 1 for the year 2006 and 0 otherwise; $\beta_{1}$ and $\beta_{2}$ were the coefficients corresponding to 2004 and $2006 ; u_{j}$ were the herd random effects, which were normally distributed with mean 0 and variance $\sigma_{j}^{2}$; and $\varepsilon_{i j}$ was the vector of residual errors, which were normally distributed with mean 0 and variance $\sigma_{i j}^{2}$. Parameters for this model were estimated in a Bayesian framework using MCMC in WinBUGS as described above.

\section{Model 3: Herd-Level Model of the Prevalence of High SCC After Calving}

Overview. The aim of the third model was to assess whether predictors that were identified as important at the individual cow level (e.g., parity and milk yield at drying off) in model 1 could be aggregated at the 
High SCC at the last milk recording before drying off

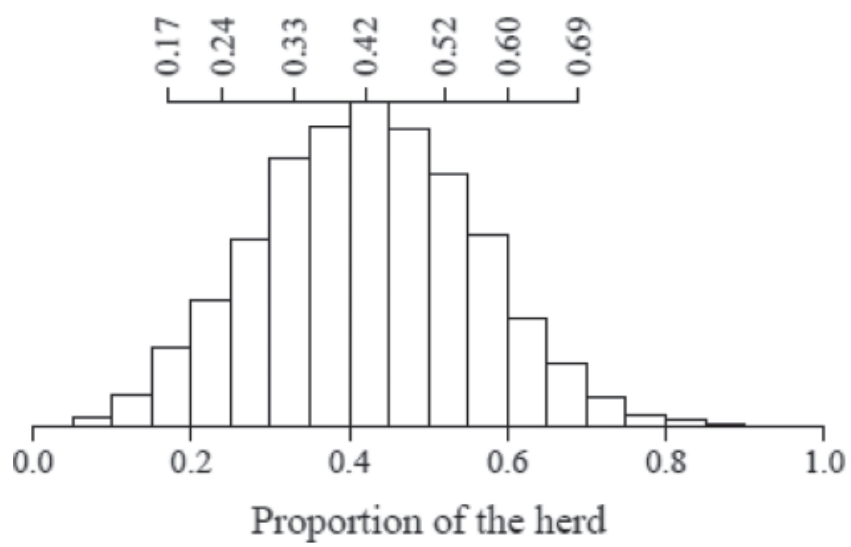

Apparent cure rate

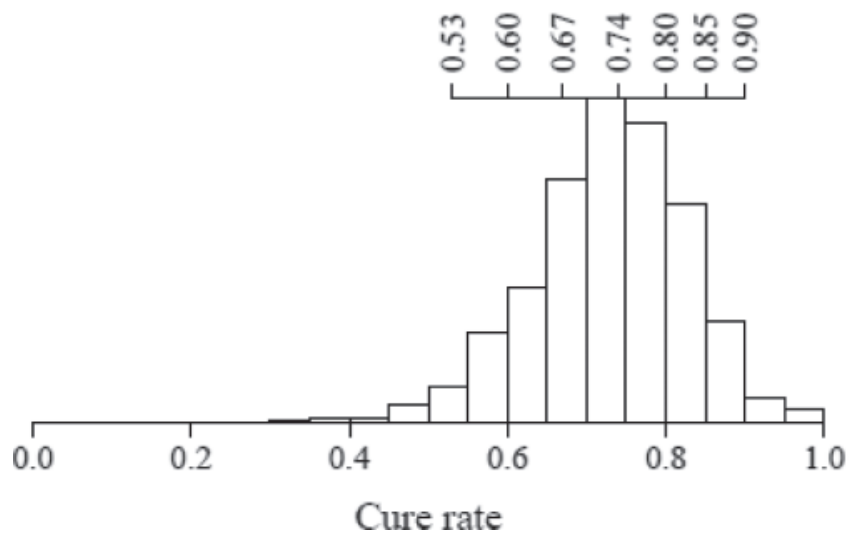

High SCC at the first milk recording after calving

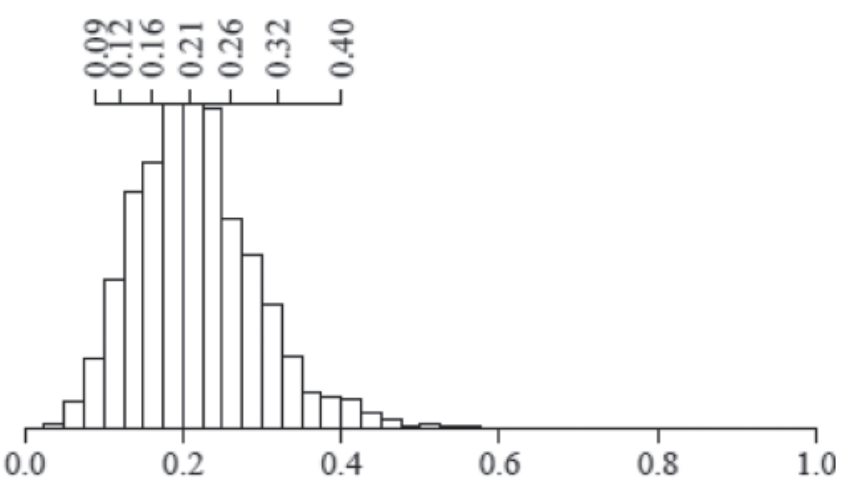

Proportion of the herd

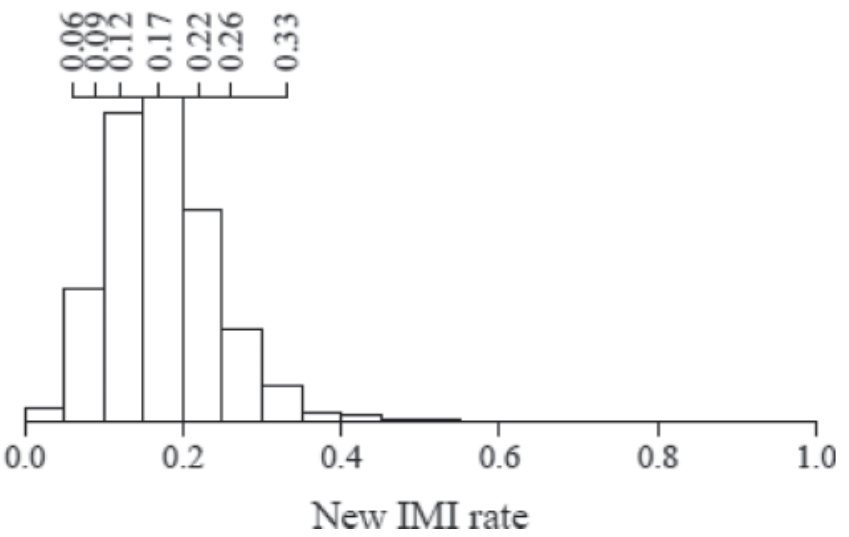

Figure 2. Distribution of the variables related to the dynamics of SCC during the dry period aggregated at the herd level for cows calving in 2004 and 2005 in 2,000 herds. The bars at the top give percentiles 2.5, 10, 25, 50, 75, 90, and 97.5 of the distributions.

herd-year level (e.g., herd-year mean parity and mean milk yield at drying off) and used as predictors of the herd-year prevalence of high SCC. The herd proportion of cows with a high SCC at the first milk recording in lactation for cows calving in 2005 was modeled. This was to allow the use of the herd data for 2004 to predict 2005.

Model Specification. The model specification was

$$
\begin{gathered}
Y_{i}=\alpha+\mathbf{X}_{04} \beta+\mathbf{X}_{05} \gamma+\varepsilon_{i} \\
\varepsilon_{i} \sim \operatorname{Normal}\left(0, \sigma_{i}^{2}\right),
\end{gathered}
$$

where $Y_{i}$ was the herd proportion of high SCC at the first milk recording in lactation in 2005; $\alpha$ was the intercept of the model; $\mathbf{X}_{04}$ was a matrix of predictors for herd historical data (i.e., from cows calving in 2004);
$\mathbf{X}_{05}$ was a matrix of predictors for cow characteristics at drying off for cows that calved in 2005; and $\varepsilon_{i}$ was the vector of residual errors, which were normally distributed with mean 0 and variance $\sigma_{i}^{2}$. Parameters for this model were estimated using least squares in $\mathrm{R}$.

\section{RESULTS}

\section{Data}

From the 2,000 herds used, data were available for 422,219 lactations in 270,441 cows. Almost half of the cows that had a milk recording between 5 and 35 DIM were starting their second or third lactation. Mean (2.5th to 97.5th percentiles) milk production at the last milk recording before drying off was $14.6 \mathrm{~kg}$ (4.4 to $27.9 \mathrm{~kg}$ ). The number of calvings was lowest in January 
Table 1. Results of the final Bayesian multilevel logistic regression model (model 1) for the probability of a cow remaining with a high SCC before and after the dry period (failure to cure)

\begin{tabular}{|c|c|c|c|c|c|}
\hline \multirow[b]{3}{*}{ Variable } & \multirow[b]{3}{*}{ Time $^{1}$} & \multicolumn{4}{|c|}{ Coefficient } \\
\hline & & \multirow[b]{2}{*}{ Mean } & \multirow[b]{2}{*}{$\mathrm{SD}$} & \multicolumn{2}{|c|}{ Credible interval } \\
\hline & & & & $2.5 \%$ & $97.5 \%$ \\
\hline Intercept & & -1.22 & 0.04 & -1.31 & -1.13 \\
\hline \multicolumn{6}{|l|}{ Cow covariate } \\
\hline Milk $^{2}$ & $\mathrm{~T}_{0}$ & 0.65 & 0.03 & 0.58 & 0.71 \\
\hline Parity $^{2}$ & $\mathrm{~T}_{0}$ & 0.54 & 0.03 & 0.49 & 0.59 \\
\hline Parity $^{2} 2$ & $\mathrm{~T}_{0}$ & -0.13 & 0.02 & -0.18 & -0.08 \\
\hline $\mathrm{DIM}^{2}$ & $\mathrm{~T}_{1}$ & -0.26 & 0.02 & -0.29 & -0.23 \\
\hline $\mathrm{DIM}^{2} 2$ & $\mathrm{~T}_{1}$ & 0.21 & 0.02 & 0.17 & 0.25 \\
\hline DIM $^{32}$ & $\begin{array}{l}\mathbf{L}_{1} \\
\mathrm{~T}_{1}\end{array}$ & -0.09 & 0.02 & -0.14 & -0.04 \\
\hline $\cos \left(\mathrm{TYR}^{3}\right)$ & Calving & $-6.01 \mathrm{E}-3$ & 0.01 & -0.3 & 0.02 \\
\hline $\sin (\mathrm{TYR})$ & Calving & 0.21 & 0.01 & 0.19 & 0.24 \\
\hline $\cos (2 \mathrm{TYR})$ & Calving & 0.05 & 0.01 & 0.03 & 0.08 \\
\hline $\sin (2 \mathrm{TYR})$ & Calving & -0.04 & 0.01 & -0.06 & -0.01 \\
\hline \multicolumn{6}{|l|}{ Herd covariates } \\
\hline High SCC at drying off ${ }^{4}$ & $\mathrm{~T}_{0}$ & 0.61 & 0.08 & 0.45 & 0.77 \\
\hline 1 - cure rate & $\mathrm{T}_{0}$ to $\mathrm{T}_{1}$ & 1.42 & 0.09 & 1.24 & 1.60 \\
\hline
\end{tabular}

and highest between mid-August and mid-November. Distributions of herd SCC dynamics and cow characteristics associated with the dry period are in Figures 1 and 2 , respectively. The median (2.5th to 97.5 th percentiles) proportion of high SCC went from $42 \%$ (17 to $69 \%$ ) to $21 \%$ (9 to $40 \%$ ) between the last milk recording in lactation and the first milk recording following calving, with important variation between herds. This was matched by an average cure rate of $74 \%$ ( 53 to $90 \%$ ) and an average new IMI rate of $17 \%$ (6 to $33 \%$ ).

\section{Model 1: Cow-Lactation Probability of High SCC After Calving}

The results of the final model for the probability of individual cow high SCC following calving are in

Table 2. Results of the final Bayesian multilevel logistic regression model (model 1) for the probability of a new IMI

\begin{tabular}{|c|c|c|c|c|c|}
\hline \multirow[b]{3}{*}{ Variable } & \multirow[b]{3}{*}{ Time $^{1}$} & \multicolumn{4}{|c|}{ Coefficient } \\
\hline & & \multirow[b]{2}{*}{ Mean } & \multirow[b]{2}{*}{$\mathrm{SD}$} & \multicolumn{2}{|c|}{ Credible interval } \\
\hline & & & & $2.5 \%$ & $97.5 \%$ \\
\hline Intercept & & -1.03 & 0.07 & -1.16 & -0.90 \\
\hline \multicolumn{6}{|l|}{ Cow-level covariate } \\
\hline Milk $^{2}$ & $\mathrm{~T}_{0}$ & 0.41 & 0.04 & 0.35 & 0.48 \\
\hline Parity $^{2}$ & $\mathrm{~T}_{0}$ & 0.55 & 0.04 & 0.47 & 0.62 \\
\hline Parity ${ }^{2}$ & $\mathrm{~T}_{0}$ & -0.17 & 0.03 & -0.23 & -0.12 \\
\hline $\mathrm{DIM}^{2}$ & $\mathrm{~T}_{1}$ & -0.37 & 0.02 & -0.40 & -0.33 \\
\hline $\mathrm{DIM}^{22}$ & $\mathrm{~T}_{1}$ & 0.20 & 0.02 & 0.16 & 0.25 \\
\hline $\mathrm{DIM}^{32}$ & $\mathrm{~T}_{1}$ & -0.16 & 0.02 & -0.21 & -0.12 \\
\hline $\cos \left(\mathrm{TYR}^{3}\right)$ & Calving & -0.01 & 0.01 & -0.04 & 0.01 \\
\hline $\sin (\mathrm{TYR})$ & Calving & 0.19 & 0.01 & 0.17 & 0.22 \\
\hline $\cos (2$ TYR $)$ & Calving & 0.08 & 0.01 & 0.06 & 0.11 \\
\hline $\sin (2$ TYR $)$ & Calving & -0.01 & 0.01 & -0.04 & 0.02 \\
\hline \multicolumn{6}{|l|}{ Herd-level covariate } \\
\hline Low $\mathrm{SCC}^{4}$ & $\mathrm{~T}_{0}$ & -0.77 & 0.09 & -0.94 & -0.60 \\
\hline New infection rate & $\mathrm{T}_{0}$ to $\mathrm{T}_{1}$ & 1.62 & 0.14 & 1.35 & 1.89 \\
\hline
\end{tabular}

${ }^{1} \mathrm{~T}_{0}=$ last milk recording of lactation; $\mathrm{T}_{1}=$ first milk recording in the following lactation.

${ }^{2}$ Legendre polynomials.

${ }^{3} \mathrm{TYR}=$ day of the year at calving $(1$ to 366$) / 366 \times 2 \times \pi$.

${ }^{4}$ Herd proportion of cows that calved in 2004 with $\mathrm{SCC}<200,000$ cells/mL at drying off. 
Table 3. Standard deviations of and correlation between the herd level intercepts in model 1 (Tables 1 and 2)

\begin{tabular}{lcccc}
\hline & \multicolumn{4}{c}{ Coefficient } \\
\cline { 2 - 5 } & & & \multicolumn{2}{c}{ Credible interval } \\
\cline { 3 - 5 } & Mean & $\mathrm{SD}$ & $2.5 \%$ & $97.5 \%$ \\
\hline Variable & 0.31 & 0.01 & 0.29 & 0.34 \\
Intercept: 1 - cure & 0.35 & 0.01 & 0.33 & 0.38 \\
Intercept: new IMI & 0.82 & 0.04 & 0.74 & 0.91 \\
Correlation & & & &
\end{tabular}

Tables 1 to 3 . For each coefficient, mean, standard deviation, and credible interval are reported. The lowest and highest bounds of the credible interval were the 2.5th and 97.5th percentiles of the MCMC samples from the coefficient's posterior distribution. Overall, good agreement was found between the observed and predicted probabilities of having a high SCC on the first milk recording after calving (Figure 3). Predicted effects of the retained variables on the new IMI and cure rates are presented in Figure 4 for baseline rates and variables related to herd history, and in Figure 5 for lactation level predictors. After having accounted for model covariates, correlation within a herd was observed between the probability of its cows remaining high and becoming high during the dry period. The estimated mean (2.5th percentile to 97.5 th percentile) of this correlation coefficient was 0.82 (0.74 to 0.91; Table 3). Covariates that were associated with a higher cure rate were associated with a lower new IMI rate. The probability of having a high SCC at the first milk recording in a lactation increased with the herd proportion of cows with a high SCC at drying off during the previous year, lower herd cure rate and higher new IMI rate, higher milk production at the last milk recording in lactation, and greater parity. The probability of a cow having a high SCC in the first milk recording was constant from December to June and then decreased
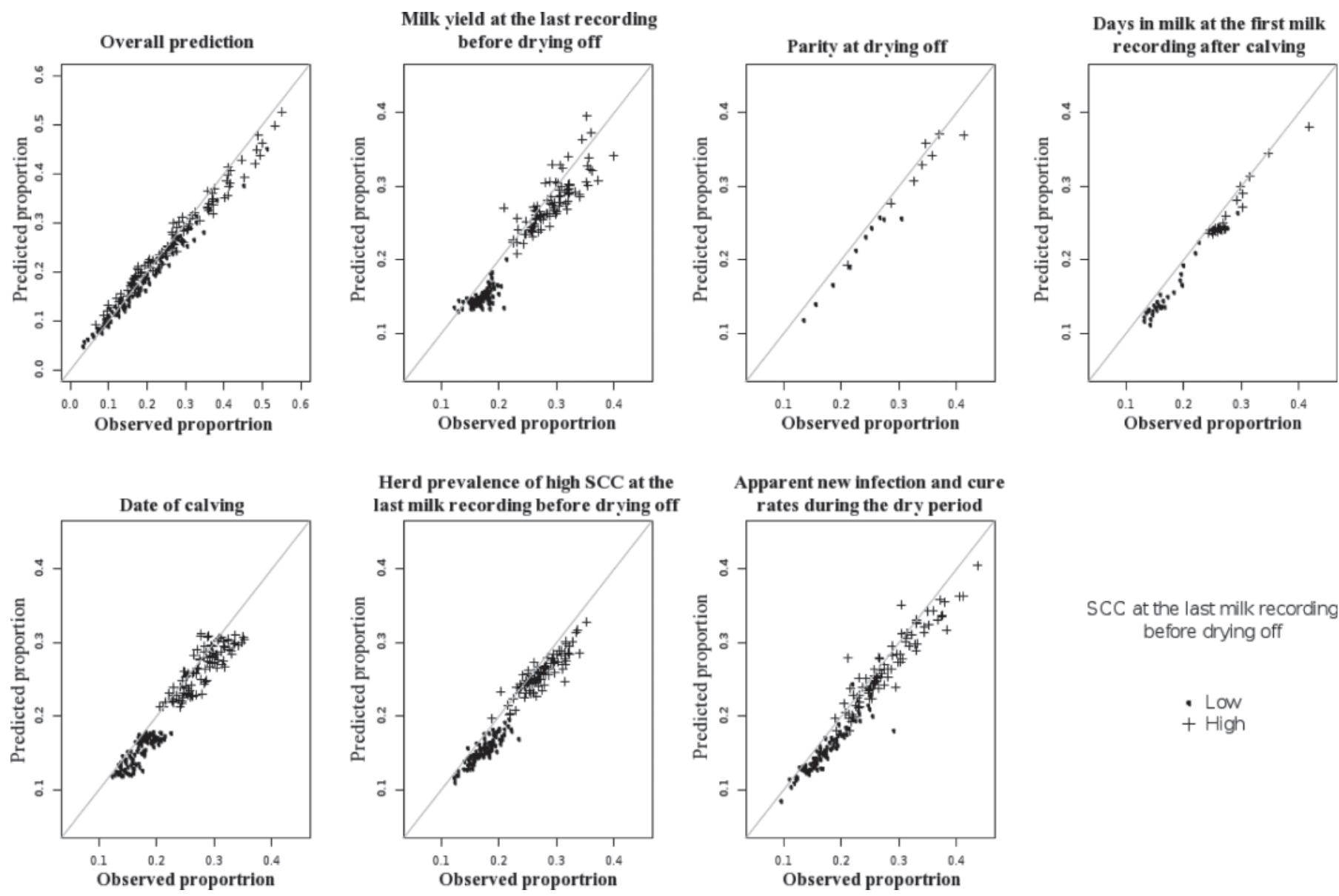

SCC at the last milk recording before drying off

- Low

+ High

Figure 3. Observed versus predicted probability of a high SCC at the first milk recording in lactation for the Bayesian multilevel logistic regression. Subgroups (bins) were created based on percentiles except for parity at drying off and DIM at first milk recording for which bins were created based on the number of discrete values the variable could take. For each bin, the mean predicted probability is plotted against the observed proportion. 


\section{Baseline new IMI and cure rates}

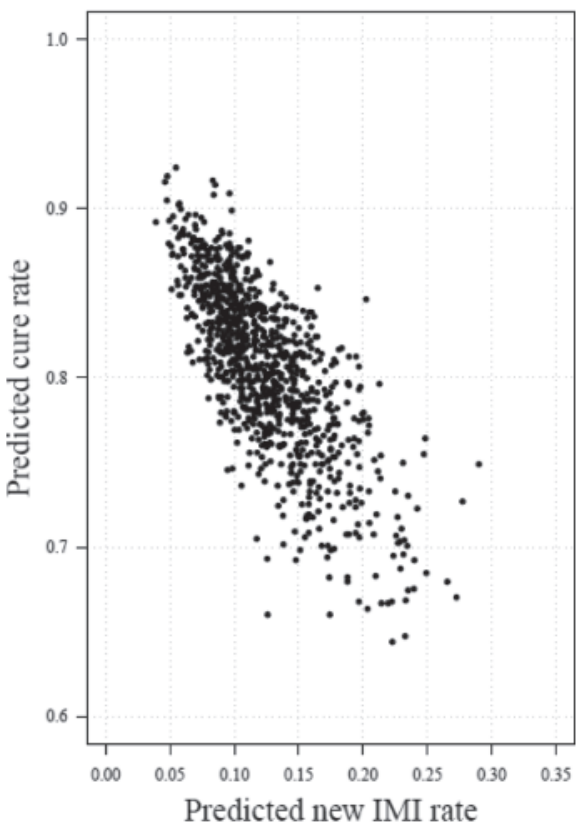

Herd prevalence of high SCC at drying off during the previous year

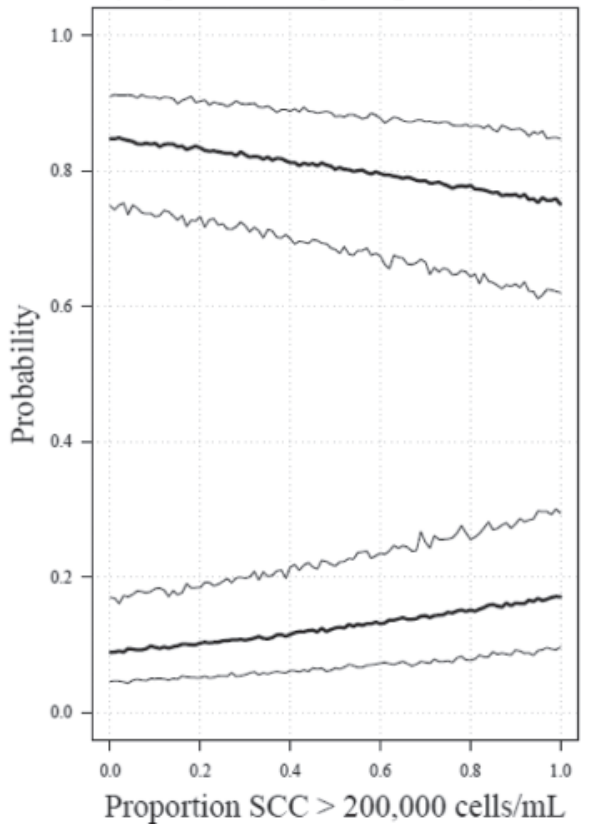

Herd cure and new IMI rates during the previous year

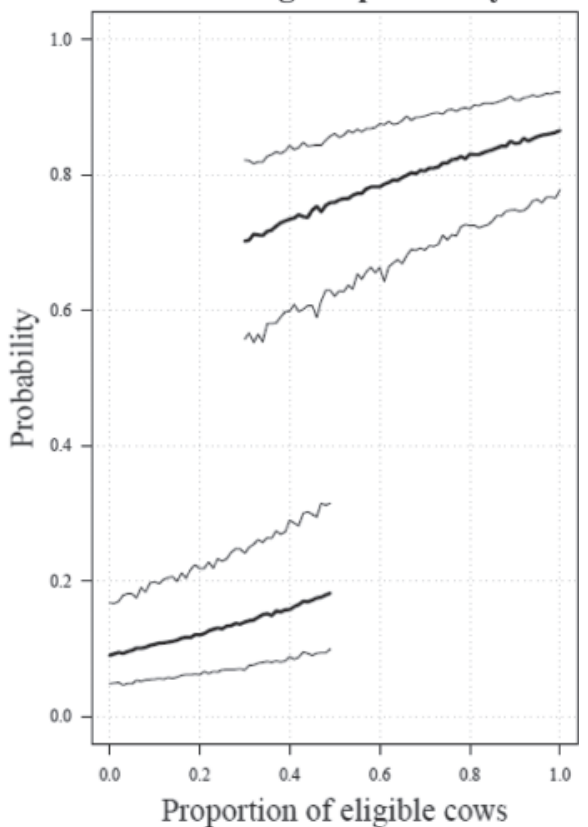

Figure 4. Posterior predictive simulations of the new IMI (x-axis of left-hand panel, lower part of the middle and right-hand panels) and cure rates (y-axis of left-hand panel, upper part of the middle and right-hand panels) from the Bayesian multilevel logistic regression. All variables were held at a plausible value and only the variable investigated was varied. Simulations were generated for a cow in her first lactation at drying off, producing $15 \mathrm{~kg}$ of milk on the last milk recording before drying off, calving in July (d 200), in a herd in which $40 \%$ of the cows had a high SCC at drying off, a cure rate of $73 \%$, and a new IMI rate of $17 \%$. Thick and thin lines represent the median and $95 \%$ credibility intervals of the simulations, respectively.

to reach a nadir in September. The probability of high SCC started high and then decreased between 5 and 20 DIM and remained approximately constant from 20 until 35 DIM (Figure 5).

When individual cow data were aggregated at the herd level, the full model explained $85 \%$ of the betweenherd variability (Table 4). Removing the herd-specific intercepts $\left(u_{j}^{c}\right.$ and $\left.u_{j}^{N}\right)$ reduced the adjusted coefficient of determination to 0.24 , indicating that the fixed effects included in the model accounted for approximately $24 \%$ of the total variability. Parity, calving date, and DIM at first milk recording explained a small part of the variability. Their removal from the model reduced the adjusted coefficient of determination of the linear model between observed and predicted to between 0.80 and 0.82 . Milk yield at drying off had a relatively large effect. By removing it from the prediction, the adjusted coefficient of determination decreased to 0.74 , which was of the same order of magnitude as the decrease induced by the removal of the herd proportion of high SCC at drying off for cows calving in 2004 (0.75) and the herd new IMI and cure rates for cows calving in 2004 (0.72). Using the same full model's fixed as well as specific herd effects to predict what would happen in 2006 yielded an adjusted coefficient of determination of 0.36 .

\section{Model 2: Between-Herd and Between-Herd-Year Variability in the Prevalence of High SCC After Calving}

Results of the model for the herd proportion of high SCC between 5 and 35 DIM are in Table 5. Although the mean proportion increased from 2004 to 2006, differences between years were very small. The herd random effect standard deviation (6.8) was slightly higher than the residual standard deviation (6.3). This suggested that herds vary importantly from one year to the next and this variation is almost as important as the variation between herds.

\section{Model 3: Herd-Level Model of the Prevalence of High SCC After Calving}

Last, the herd prevalence of high SCC between 5 and 35 DIM for cows calving in 2005 was modeled as a function of the herd historical data (i.e., herd prevalence of high SCC before drying off, cure rate, and new IMI rate for cows calving in 2004). Because they were identified as important predictors in the cow-level model, herd summaries for parity and milk yield at drying off in 2005 were forced into the model. The results of this model are in Table 6. The adjusted coefficient of determination was 0.33 . Mean and standard deviation of 
milk yield before drying off were better predictors than the proportion of the herd in milk production grouped in quintiles ( $<10 \mathrm{~kg}, 10$ to $<13 \mathrm{~kg}, 13$ to $<16 \mathrm{~kg}, 16$ to $<29 \mathrm{~kg}$, and $\geq 29 \mathrm{~kg}$ ). Proportions of the herd in groups of cow parities at drying off $(1,2,3$, and $>3)$ were entered in the model, and the proportion of primiparous cows dried off only was a significant predictor. Removing the variables related to milk yield before drying off

\section{Milk yield at last milk recording}

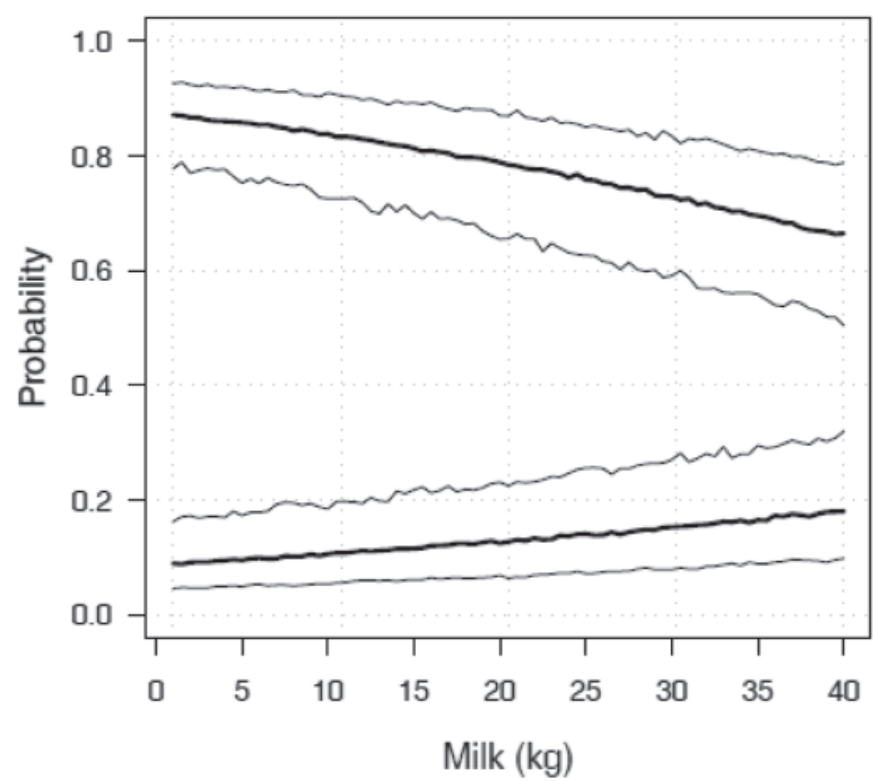

Calving date

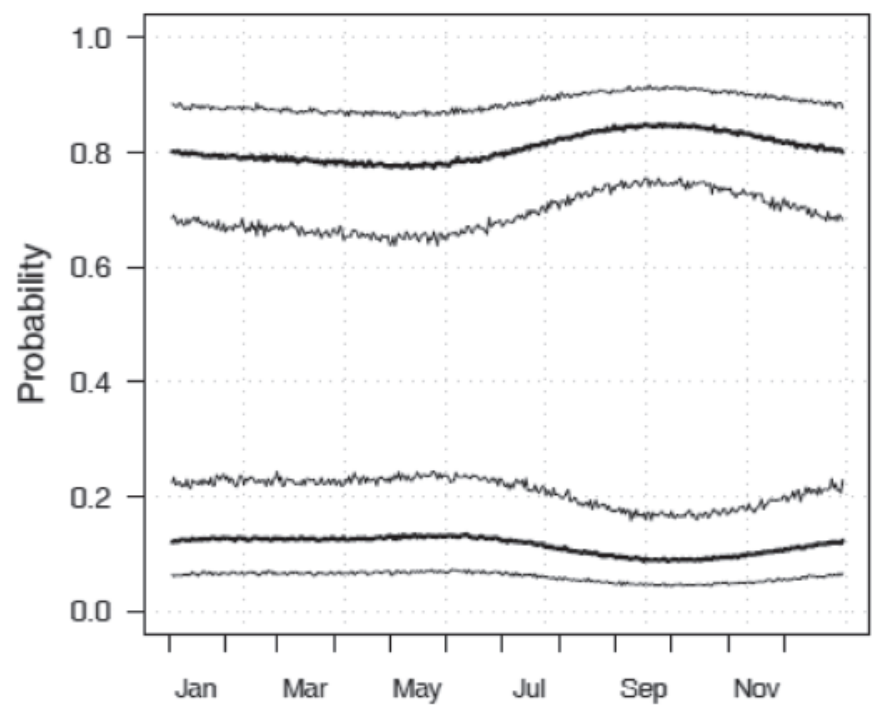

Day of the year
Parity at drying off

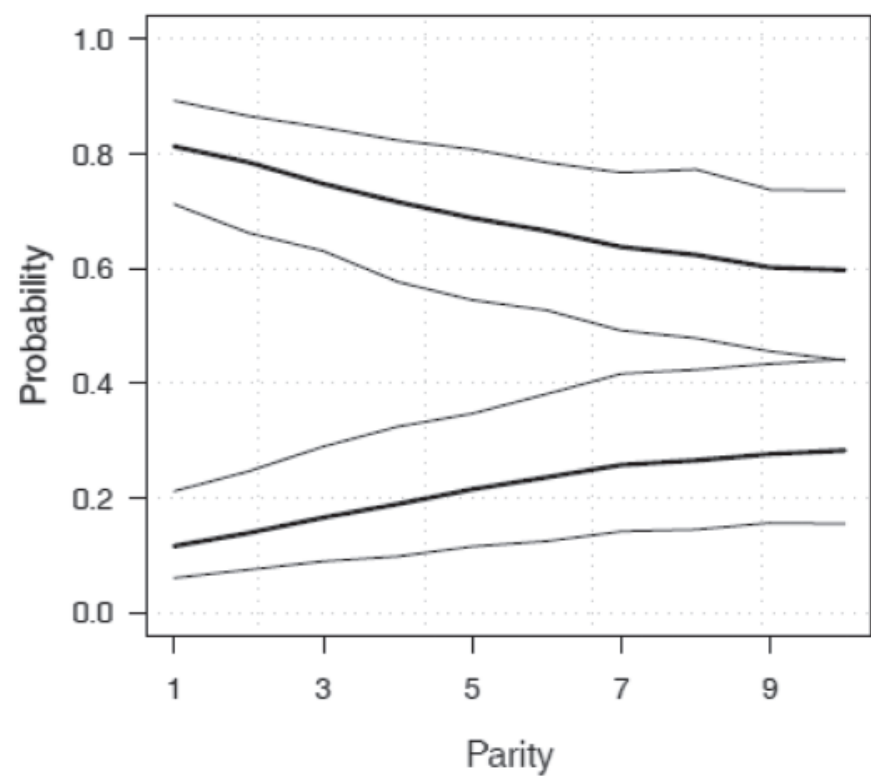

DIM at first milk recording

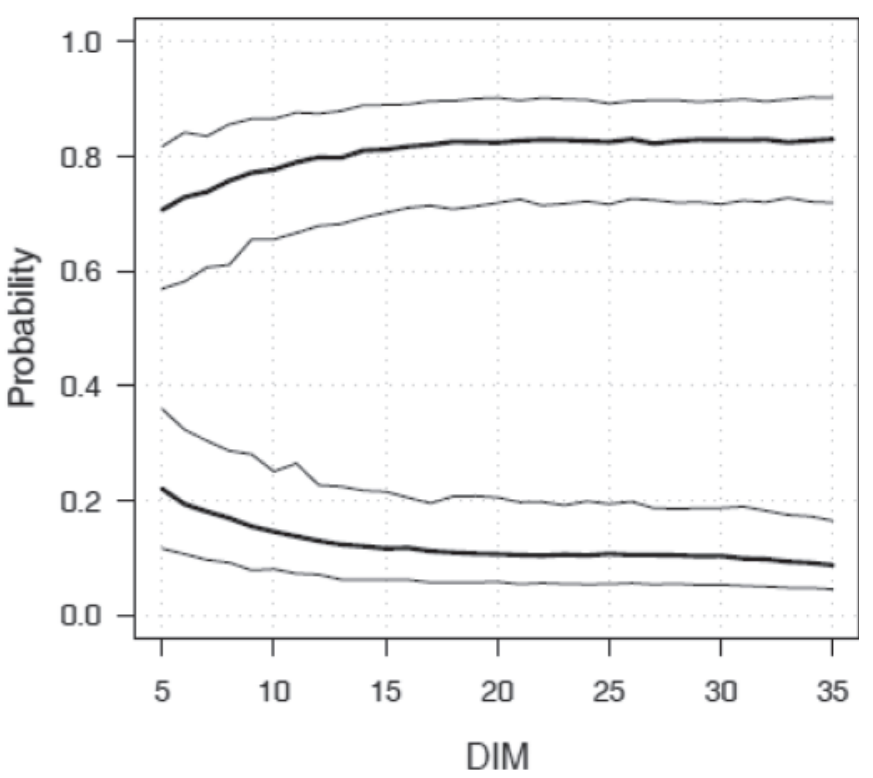

Figure 5. Posterior predictive simulations of the new IMI (lower part of each plot) and cure rates (upper part of each plot) from the Bayesian multilevel logistic regression. All variables were held at a plausible value and only the variable investigated was varied. Simulations were generated for a cow in her first lactation at drying off, producing $15 \mathrm{~kg}$ of milk on the last milk recording before drying off, calving in July (d 200), in a herd in which $40 \%$ of the cows had a high SCC at drying off, a cure rate of $73 \%$, and a new IMI rate of $17 \%$. Thick and thin lines represent the median and $95 \%$ credibility intervals of the simulations, respectively. 
Table 4. Association between proportions predicted by posterior predictive simulation and observed herd proportion of high SCC between 5 and 35 DIM for different subsets of model 1 with the different covariates sequentially removed ${ }^{1}$

\begin{tabular}{lccc}
\hline Variable removed from the model & $\alpha$ & $\beta$ & Adjusted $\mathrm{R}^{2}$ \\
\hline None & -0.06 & 1.40 & 0.85 \\
Parity & -0.09 & 1.34 & 0.82 \\
Milk yield at drying off & -0.03 & 1.24 & 0.74 \\
DIM at first recording & -0.06 & 1.55 & 0.80 \\
Calving date & -0.05 & 1.53 & 0.81 \\
Herd proportion of cows with high SCC during the previous year & -0.13 & 1.75 & 0.75 \\
Herd apparent new IMI and cure rates during the previous year & -0.16 & 1.96 & 0.72 \\
Herd random effect & 0.01 & 1.20 & 0.24 \\
\hline
\end{tabular}

${ }^{1} \alpha$ is the intercept and $\beta$ the slope in the models.

from the model decreased the adjusted coefficient of determination from 0.33 to 0.29 .

\section{DISCUSSION}

Approximately one-third of the between-herd variability in the percentage of SCC $>200,000$ at the first milk recording in a lactation could be predicted from past performance and individual cow characteristics. Herd influence on the probability of high SCC in early lactation was split between a fixed historical component that quantified the association between past and current performance and a herd effect aimed at capturing the remaining unexplained variation. This last parameter was the biggest contributor to the predicted performance.

Even though individual cow characteristics explained a small amount of the differences that existed between herds, they had a notable effect on the probability of having a high SCC at the first milk recording in lactation. Accounting for these factors in studies on SCC in early lactation is important. The most important

Table 5. Results of the Bayesian multilevel model of the herd-year proportion of high SCC between 5 and 35 DIM for the years 2004 to $2006^{1}$

\begin{tabular}{|c|c|c|c|c|}
\hline \multirow[b]{3}{*}{ Variable } & \multicolumn{4}{|c|}{ Coefficient } \\
\hline & \multirow[b]{2}{*}{ Mean } & \multirow[b]{2}{*}{$\mathrm{SD}$} & \multicolumn{2}{|c|}{ Credible interval } \\
\hline & & & $2.5 \%$ & $97.5 \%$ \\
\hline Intercept & 21.7 & 0.2 & 21.3 & 22.1 \\
\hline Calv $_{04}{ }^{1}$ & -0.6 & 0.2 & -1.0 & -0.2 \\
\hline Calv $_{06}^{2}$ & 0.5 & 0.2 & 0.1 & 0.9 \\
\hline$\sigma_{j}^{3}$ & 6.3 & 0.1 & 6.1 & 6.4 \\
\hline$\sigma_{i j}^{4}$ & 6.8 & 0.1 & 6.5 & 7.1 \\
\hline \multirow{2}{*}{\multicolumn{5}{|c|}{$\begin{array}{l}{ }^{1} \text { Coefficients have been multiplied by } 100 \text { to allow interpretation a } \\
\text { percentage. }\end{array}$}} \\
\hline & & & & \\
\hline \multicolumn{5}{|c|}{${ }^{1}$ Cows calving in 2004} \\
\hline \multicolumn{5}{|c|}{${ }^{2}$ Cows calving in 2006.} \\
\hline \multicolumn{5}{|c|}{${ }^{3}$ Herd random effects standard deviation. } \\
\hline
\end{tabular}

individual cow-level contributor to the between-herd variability was milk yield at the last milk recording before drying off. This effect was most important for cows that had a high SCC before drying off (Figures 3 and 4). An association between milk yield at drying off and the probability of infection after calving was observed consistently (Huxley et al., 2002; Dingwell et al., 2004; Rajala-Schultz et al., 2005). At least part of this association appears related to a direct effect of milk production at drying off, as altering milk yield through either a decrease in milking frequency or a limitation of feed intake in the weeks preceding drying off was associated with a decrease in IMI (Tucker et al., 2009; Newman et al., 2010). A biological explanation for this could be that cows that produce too much milk after the last milking are more likely to leak milk (Schukken et al., 1993; Tucker et al., 2009), which could prevent the formation of the keratin plug (Comalli et al., 1984). Importantly, milk yield at drying off was the only variable that explained a significant part of the betweenherd variability, suggesting that it would be possible to decrease the prevalence of high SCC following calving by altering the herd target yield at drying off. Other significant cow-level factors were parity, calving date, and DIM at first recording and although these factors had potentially large effects, these variables explained

Table 6. Results of the linear model of the herd-year proportion of high SCC between 5 and 35 DIM in $2005^{1}$

\begin{tabular}{lccc}
\hline Variable & Year & Coefficient & SE \\
\hline Intercept & & 29.2 & 1.9 \\
High SCC before drying off & 2004 & 10.4 & 1.1 \\
Cure rate & 2004 & -16.0 & 1.2 \\
New IMI rate & 2004 & 24.3 & 1.8 \\
Mean yield (kg) at drying off & 2005 & -0.3 & 0.04 \\
SD yield (kg) at drying off & 2005 & 1.3 & 0.15 \\
Proportion of parity 1 dried off & 2005 & -4.6 & 1.9 \\
\hline
\end{tabular}

${ }^{1}$ Coefficients have been multiplied by 100 to allow interpretation as percentage. For example, increasing the cure rate from 0 (no cure) to 1 (all high become low) would result in a predicted decrease of $16 \%$ of high SCC at the first milk recording in lactation. The adjusted $\mathrm{R}^{2}$ of the model was 0.33 . 
very little of the variation at the herd level. This was because most herds were similar in their distribution for these variables. It is only possible to speculate on the reasons for a higher cure rate and a lower new IMI rate for cows calving between July and November. This roughly corresponds to the time when the number of calvings was higher, which could coincide with greater attention, but also to higher animal density. Another explanation could be that more of these cows have spent their dry period on pasture rather than indoors and this resulted in a change in the risk of new IMI (Green et al., 2008).

The definitions of cures and new IMI used were based on 2 SCC samples collected in the month before drying off and in the month following calving. Between these 2 recordings, some cows infected at drying off may have cured their IMI and become re-infected, leading to an apparent absence of cure, when a cure was followed by a new IMI. This is plausible, as cures more likely happen at the beginning of the dry period, after dry cow therapy has been administered, and new IMI could happen as the efficacy of the antibiotic treatment has faded out, during the colostrogenesis and early lactation phases, when the mammary gland becomes more sensitive to IMI again (Bradley and Green, 2004). This certainly happens for some cows, but it is impossible from the present data to determine the proportion. It could explain the elevated estimated correlation between the probabilities of remaining and becoming high of 0.85 . Cure rates based on SCC should be interpreted in conjunction with the new IMI rates and high values could be indicative of reinfection following a cure.

\section{CONCLUSIONS}

Important between-herd variability in the dynamics of SCC exists during the dry period as measured by movements across a threshold of 200,000 cells $/ \mathrm{mL}$ between the last milk recording in a lactation and the first milk recording in the following lactation. Although the probability for a cow of having a high SCC varies with factors such as parity, DIM at the first milk recording, or calving date, the only risk factor for high SCC that is significant in explaining both between-cow and between-herd performance is milk yield at the last milk recording before drying off. Decreasing milk yield at drying off can help to decrease the prevalence of high SCC following calving.

\section{ACKNOWLEDGMENTS}

We thank Pfizer Animal Health (Paris, France) for funding this research.

\section{REFERENCES}

Bates, D. and M. Maechler. 2010. lme4: Linear mixed-effects models using S4 classes. R package version 0.999375-33. Accessed Aug. 1, 2011. http://lme4.sourcearchive.com/documentation/0.999375-33-1/main.html.

Bohmanova, J., F. Miglior, J. Jamrozik, I. Misztal, and P. G. Sullivan. 2008. Comparison of random regression models with Legendre polynomials and linear splines for production traits and somatic cell score of Canadian Holstein cows. J. Dairy Sci. 91:3627-3638.

Bradley, A. J., and M. J. Green. 2000. A study of the incidence and significance of intramammary enterobacterial infections acquired during the dry period. J. Dairy Sci. 83:1957-1965.

Bradley, A. J., and M. J. Green. 2004. The importance of the nonlactating period in the epidemiology of intramammary infection and strategies for prevention. Vet. Clin. North Am. Food Anim. Pract. 20:547-568.

Bradley, A. J., and M. J. Green. 2005. Use and interpretation of somatic cell count data in dairy cows. In Pract. 27:310-315.

Browne, W. J., F. Steele, M. Golalizadeh, and M. J. Green. 2009. The use of simple reparameterizations to improve the efficiency of Markov chain Monte Carlo estimation for multilevel models with applications to discrete time survival models. J. R. Stat. Soc. Ser. A Stat. Soc. 172:579-598.

Comalli, M. P., R. J. Eberhart, L. C. Griel Jr., and H. Rothenbacher. 1984. Changes in the microscopic anatomy of the bovine teat canal during mammary involution. Am. J. Vet. Res. 45:2236-2242.

Cook, N. B., T. B. Bennett, K. M. Emery, and K. V. Nordlund. 2002. Monitoring nonlactating cow intramammary infection dynamics using DHI somatic cell count data. J. Dairy Sci. 85:1119-1126.

Dingwell, R. T., K. E. Leslie, Y. H. Schukken, J. M. Sargeant, L. L. Timms, T. F. Duffield, G. P. Keefe, D. F. Kelton, K. D. Lissemore, and J. Conklin. 2004. Association of cow and quarter-level factors at drying-off with new intramammary infections during the dry period. Prev. Vet. Med. 63:75-89.

Gelman, A., Y. Goegebeur, F. Tuerlinckx, and I. Van Mechelen. 2000. Diagnostic checks for discrete data regression models using posterior predictive simulations. Appl. Stat. 49:247-268.

Gelman, A., and J. Hill. 2007. Data Analysis Using Regression and Multilevel/Hierarchical Models. Cambridge University Press, New York, NY.

Green, M. J., A. J. Bradley, G. F. Medley, and W. J. Browne. 2007. Cow, farm, and management factors during the dry period that determine the rate of clinical mastitis after calving. J. Dairy Sci. 90:3764-3776.

Green, M. J., A. J. Bradley, G. F. Medley, and W. J. Browne. 2008. Cow, farm, and herd management factors in the dry period associated with raised somatic cell counts in early lactation. J. Dairy Sci. 91:1403-1415.

Green, M. J., L. E. Green, G. F. Medley, Y. H. Schukken, and A. J. Bradley. 2002. Influence of dry period bacterial intramammary infection on clinical mastitis in dairy cows. J. Dairy Sci. 85:25892599.

Huxley, J. N., M. J. Greent, L. E. Green, and A. J. Bradley. 2002. Evaluation of the efficacy of an internal teat sealer during the dry period. J. Dairy Sci. 85:551-561.

Lunn, D. J., A. Thomas, N. Best, and D. Spiegelhalter. 2000. WinBUGS-A Bayesian modelling framework: Concepts, structure, and extensibility. Stat. Comput. 10:325-337.

Madouasse, A. 2009. An evaluation of milk recording, somatic cell count and reproductive performance in a large cohort of dairy herds in England and Wales. PhD Thesis. University of Nottingham, Nottingham, UK.

Madouasse, A., J. N. Huxley, W. J. Browne, A. J. Bradley, I. L. Dryden, and M. J. Green. 2010a. Use of individual cow milk recording data at the start of lactation to predict the calving to conception interval. J. Dairy Sci. 93:4677-4690.

Madouasse, A., J. N. Huxley, W. J. Browne, A. J. Bradley, and M. J. Green. 2010b. Somatic cell count dynamics in a large sample of dairy herds in England and Wales. Prev. Vet. Med. 96:56-64. 
Newman, K. A., P. J. Rajala-Schultz, F. J. DeGraves, and J. Lakritz. 2010. Association of milk yield and infection status at dry-off with intramammary infections at subsequent calving. J. Dairy Res. 77:99-106.

Pantoja, J. C., C. Hulland, and P. L. Ruegg. 2009a. Dynamics of somatic cell counts and intramammary infections across the dry period. Prev. Vet. Med. 90:43-54.

Pantoja, J. C., C. Hulland, and P. L. Ruegg. 2009b. Somatic cell count status across the dry period as a risk factor for the development of clinical mastitis in the subsequent lactation. J. Dairy Sci. 92:139-148.

R Development Core Team. 2010. R: A Language and Environment for Statistical Computing. R Foundation for Statistical Computing, Vienna, Austria.

Rajala-Schultz, P. J., J. S. Hogan, and K. L. Smith. 2005. Short communication: Association between milk yield at dry-off and probability of intramammary infections at calving. J. Dairy Sci 88:577-579

Schukken, Y. H., J. Vanvliet, D. Vandegeer, and F. J. Grommers. 1993. A randomized blind trial on dry cow antibiotic infusion in a low somatic cell count herd. J. Dairy Sci. 76:2925-2930.

Schukken, Y. H., D. J. Wilson, F. Welcome, L. Garrison-Tikofsky, and R. N. Gonzalez. 2003. Monitoring udder health and milk quality using somatic cell counts. Vet. Res. 34:579-596.

Spiegelhalter, D. J., N. G. Best, B. P. Carlin, and A. van der Linde. 2002. Bayesian measure of model complexity and fit. J. R. Stat. Soc., B 64:583-639.

Tucker, C. B., S. J. Lacy-Hulbert, and J. R. Webster. 2009. Effect of milking frequency and feeding level before and after dry off on dairy cattle behavior and udder characteristics. J. Dairy Sci. 92:3194-3203 